\title{
FAKTOR YANG MEMPENGARUHI DAN ESTIMASI TARIF EKUIVALEN NTBS EKSPOR KAYU LAPIS INDONESIA
}

\author{
The NTBs Indonesian Plywood Export: Determining Factors and Estimating \\ Their Equivalent Tariff
}

\author{
Kartika Rahma Sari, Widyastutik \\ Departemen Ilmu Ekonomi, Fakultas Ekonomi dan Manajemen, Institut Pertanian Bogor \\ widyastutik_ipb@yahoo.com, kakadaryoso@yahoo.co.id
}

Naskah diterima: 17/8/2014 Naskah direvisi: 18/1/2015 Disetujui diterbitkan: 21/4/2015

\begin{abstract}
Abstrak
Studi ini bertujuan untuk menganalisis faktor-faktor yang mempengaruhi ekspor kayu lapis dengan menggunakan Gravity Model, dan menghitung Nilai Tarif Ekuivalen dari Non Tariff Barriers (NTBs) kayu lapis Indonesia di negara tujuan. Berdasarkan pendekatan Gravity Model (Model Gravitasi), aliran perdagangan potensial diperoleh dengan melakukan subtitusi seluruh data kedalam persamaan gravity. Fitted trade flow dari persamaan gravity model dianggap sebagai aliran perdagangan potensial. Perbedaan antara aliran perdagangan aktual dan potensial diindikasikan sebagai tarif ekuivalen dari NTBs. Hasil estimasi menunjukkan faktor-faktor yang berpengaruh terhadap ekspor kayu lapis Indonesia yaitu Gross Domestic Product (GDP) riil Indonesia dan negara tujuan, Indek Harga Konsumen (IHK) Indonesia dan negara tujuan, jarak ekonomi, nilai tukar dan krisis keuangan tahun 2010. Hasil perhitungan menunjukkan negara Uni Eropa seperti Inggris dan Belgia memiliki rata-rata tarif ekuivalen NTBs paling besar. Sistem Verifikasi Legalitas Kayu (SVLK) untuk legalitas produk kayu dapat dijadikan sebagai strategi untuk menghadapi NTBs yang ada di negara tujuan ekspor.
\end{abstract}

Kata Kunci: Non-Tariff Barries (NTBs), Gravity Model, Volume Ekspor, Data Panel

\begin{abstract}
This study sets out to analyze factors that influence plywood exports utilizing the Gravity Model and assess the equivalent tarriff value of Non Trade Barriers plywood on destination countries. Based on the Gravity Model approach, a potential of flow of trade is obtained through subsituting the whole data into gravity equation. Fitted trade flow from the Gravity Model equation is considered as a potential trade flow. The difference between actual and potential trade flow is indicated by the NTB equivalent tariff. The result shows factors that are influential on plywood exports notably the GDPs of Indonesia and destination countries, Consumer Index Price in Indonesia and destination countries, economic distance, exchange value and economic crisis in 2010. In addition, European Union such as England and Belgium have the highest average for NTB equivalent tariff. Verification System of Plywood legality is one alternative that can be deployed as a strategy when confronting NTB on destination countries.
\end{abstract}

Keywords: Non-Tariff Barries (NTBs), Gravity Model, Export Volume, Panel Data

JEL Classification: F02, F12, F13, F14 


\section{PENDAHULUAN}

Indonesia merupakan salah satu negara dengan luas hutan tropis terbesar ketiga setelah Brazil dan Republik Kongo di dunia. Luas hutan tropis Indonesia diperkirakan mencapai 109 juta hektar. Dengan luasan tersebut, Indonesia memiliki peringkat pertama di Asia Pasifik dan tak heran apabila Indonesia juga disebut sebagai salah satu paruparu dunia dengan banyak keragaman kekayaan hayati yang dimiliki (World Wild Foundation, 2009).

Tahun 1990-an merupakan masa keemasan kayu lapis Indonesia karena nilai ekspornya yang tiap tahun kian meningkat. Kayu lapis juga pernah menjadi satu-satunya komoditi Indonesia di pasar internasional yang berubah dari pasar pembeli (Buyer's Market) menjadi pasar penjual (Seller's Market) dan pada tahun 1992 Indonesia menjadi negara pengekspor kayu lapis terbesar di dunia (Triastuti, 1992).

Sejak tahun 1992 hingga tahun 2012, ekspor kayu lapis Indonesia mengalami fluktuasi. Pada tahun 1992 dan 1993, volume ekspor kayu lapis Indonesia mencapai 9,7 juta $\mathrm{m}^{3}$ dan 9,6 juta $\mathrm{m}^{3}$. Penurunan volume ekspor yang signifikan mulai terjadi pada tahun 1994 namun kembali mengalami peningkatan pada tahun 1995 hingga 1997. Akan tetapi, penurunan ekspor kembali terjadi pada tahun 1998 hingga tahun 2000 (lihat Gambar 1). Pada periode 1994-1998 jumlah volume ekspor kayu olahan Indonesia mencapai $90 \%$ dari perdagangan kayu dunia sehingga sempat menjadi yang terbesar di dunia mengungguli Brazil dan Malaysia yang juga mengembangkan industri pengolahan kayu.

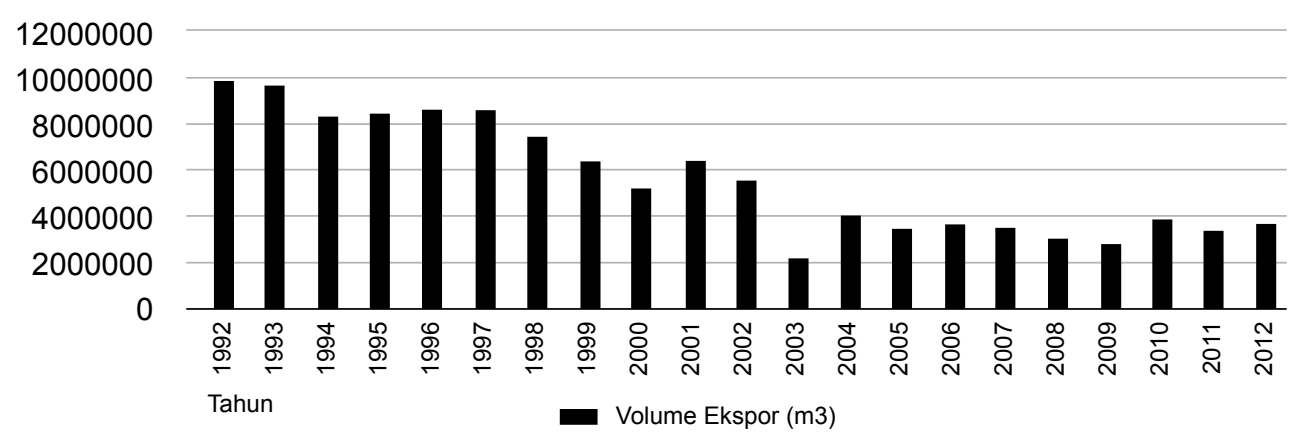

Gambar 1. Volume Ekspor Kayu Lapis Indonesia, 1992-2012

Sumber: Kemendag (2013), diolah

Penurunan ekspor kayu lapis ini disebabkan karena penurunan pasokan bahan baku. Kondisi ini juga didukung oleh data Kementerian Perindustrian yang menyatakan bahwa ekspor kayu dan produk kayu Indonesia mengalami penurunan. Pada tahun 2006 ekspor kayu dan barang dari kayu nasional mencapai Rp 3,3 triliun, tetapi tahun 2007 turun menjadi Rp 3,1 triliun (Dinas Kehutanan Provinsi Jawa Barat, 2015). Ekspor panel kayu dan kayu olahan (woodworking) juga turun, pada tahun 2006, ekspor panel kayu mencapai 3,5 juta ton dan kayu olahan 2,3 juta ton. Sedangkan pada tahun 2007, realisasi ekspor panel kayu hanya 2,6 juta ton dan kayu olahan 1,6 juta ton. Pertumbuhan industri hasil kayu serta pengolahan tahun 2006 dan 2007 lebih rendah dari pertumbuhan ekonomi karena banyaknya pembalakan liar. Berdasarkan Laporan Status Lingkungan Hidup Indonesia tahun 2006 menyebutkan angka laju deforestasi 
mencapai 1,19 juta hektar per tahun (Kementerian Lingkungan Hidup, 2006).

Oleh sebab itu, pemerintah memberlakukan kebijakan pengetatan izin usaha untuk pengelolaan hasil hutan terutama kayu. Tujuan utama dari kebijakan tersebut adalah mengurangi penebangan liar (illegal logging) dari perusahaan-perusahaan penyedia bahan baku pengolahan kayu.

Pada rentang tahun 2001 hingga tahun 2012 pasar Jepang masih mendominasi sebagai negara tujuan ekspor kayu lapis Indonesia dengan proporsi $45 \%$ dari total seluruh ekspor kayu lapis Indonesia. Selain Jepang, dominasi tujuan ekspor kayu lapis Indonesia adalah RRT (10\%), Korea Selatan (8\%) dan Amerika Serikat. Pada rentang 2001 hingga 2012, pasar Amerika Serikat mampu menampung ekspor kayu lapis Indonesia sebesar 9\% dari total ekspor kayu lapis Indonesia ke sepuluh negara tujuan utama ekspor. Angka ini lebih tinggi dibandingkan dengan Taiwan (8\%) dan Korea Selatan (8\%). Negara Timur Tengah yang termasuk dalam 10 negara utama tujuan ekspor kayu lapis Indonesia adalah Saudi Arabia sebesar $7 \%$ dan Uni Emirat Arab sebesar 5\%. Negara Uni Eropa yang termasuk dalam sepuluh negara utama tujuan ekspor kayu lapis Indonesia adalah Belgia dan Inggris yang memiliki proporsi yang sama terhadap ekspor kayu lapis nasional sebesar 3\% lebih besar daripada Singapura sebesar 2\% (Gambar 2).

Penelitian Dwiprabowo (2009) menyebutkan bahwa Indonesia bersama dengan Malaysia menjadi produsen produk hasil olahan kayu di pasar dunia terutama untuk kayu lapis keras tropik (tropical hardwood plywood) selama bertahun-tahun. Puncaknya di tahun 1992 ekspor kayu lapis Indonesia

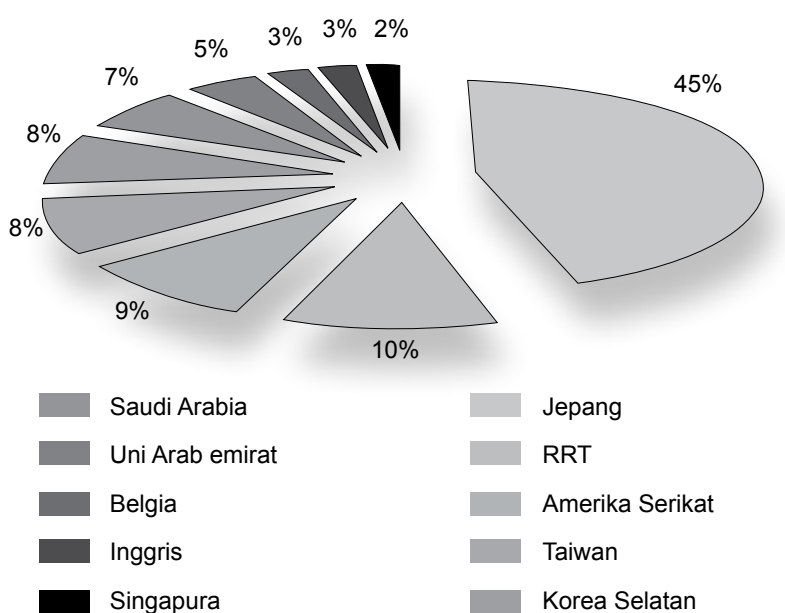

Gambar 2. Sepuluh Negara Tujuan Ekspor Utama Kayu Lapis Indonesia

Sumber: UN COMTRADE (2013), diolah

mencapai volume ekspor tertinggi hingga 9,7 juta $\mathrm{m}^{3}$. Angka tersebut menunjukkan Indonesia pada tahun 1992 mendominasi perdagangan kayu lapis di pasar dunia. Akan tetapi, pada tahun-tahun berikutnya volume ekspor Indonesia cenderung menurun, bahkan menurun drastis pada tahun 2003 (lihat Gambar 1). Meskipun pada perkembangannya, pada tahun tersebut volume eksporkayu lapis Malaysia masih berada di bawah Indonesia. Namun yang terjadi Malaysia cenderung mengalami peningkatan secara konsisten pada tahun-tahun berikutnya. Pada tahun 2004, volume ekspor kayu lapis Malaysia mampu melampaui volume ekspor kayu lapis Indonesia, sehingga pada tahun tersebut Malaysia mulai menggeser posisi Indonesia sebagai pengekspor dominan kayu lapis di pasar dunia.

Di wilayah Asia Tenggara, negaranegara ASEAN telah membuat kesepakatan perdagangan regional kawasan ASEAN yaitu ASEAN Free Trade Area (AFTA) yang telah disepakati pada tahun 2003. Secara bertahap pada tahun 2007, bea masuk dengan tingkat $0 \%$ minimal $80 \%$ dari Inclusion 
List, dan tahun 2010 seluruh tarif bea masuk dengan tingkat tarif $0 \%$ harus sudah 100\% untuk anggota ASEAN (Kementerian Keuangan, 2013).

Kondisi tersebut menjadi peluang sekaligus tantangan bagi masing-masing negara untuk meningkatkan daya saing produknya. Ketika tingkat tarif diberbagai negara diturunkan secara berarti melalui serangkaian negosiasi perdagangan multilateral, jumlah dan peranan berbagai bentuk hambatan perdagangan non-tarif justru melonjak (Salvatore, 2007). Pergeseran bentuk hambatan perdagangan tersebut memberikan dampak terhadap perdagangan komoditi bilateral dan multilateral. Pada implementasinya, terdapat beberapa peraturan teknis dikeluarkan oleh World Trade Organization (WTO) dalam GATT (General Agreement on Tarrif and Trade) terkait NTBs (Non-Tariff Barriers) seperti larangan terhadap tindakan dumping (diskriminasi harga secara internasional), larangan terhadap hambatan perdagangan teknis (technical barrier to trade), pengutamaan keselamatan produk (safeguard), larangan terhadap isu pemberian subsidi yang berlebihan dari pemerintah terhadap eksportir (subsidies and countervailing measures), peraturan pemerintah suatu negara dalam menjaga keamanan makanan, kesehatan hewan dan tumbuhan (sanitary and phytosanitary), serta kewajiban yang harus dilakukan oleh pemerintah dan non-pemerintah dalam kegiatan perdagangan yang didalamnya termasuk kegiatan ekspor dan impor produk atau komoditi (WTO, 2013a, 2013b, 2013c). Hambatan perdagangan baik tarif mapun non tarif akan mempengaruhi ekspor kayu lapis Indonesia ke Negara tujuan ekspor utama.

Terkait dengan hal tersebut di atas tulisan ini bertujuan untuk mengetahui faktor-faktor yang mempengaruhi ekspor kayu lapis (HS digit 4 yaitu 4412 plywood, veneer and laminated wood) Indonesia ke negara tujuan utama ekspor yaitu yaitu Jepang, RRT, Amerika Serikat, Korea Selatan, Saudi Arabia, Uni Emirat Arab, Belgia, Inggris dan Singapura dengan model gravity. Model Gravity dipilih karena dengan model ini memungkinkan untuk melakukan pendekatan quantity based model. Selanjutnya berdasarkan pendekatan quantity based measures, dari model gravity dapat digunakan untuk menghitung besaran tarif ekuivalen dari NTBs (hambatan non tarif) yang dikenakan oleh Negara tujuan ekspor utama. Jager dan Lanjouw (1977) menyatakan argumentasinya bahwa quantity based measures cenderung lebih dipilih daripada price-based measures karena pengukuran tersebut lebih menjelaskan apa yang ingin diketahui tentang efek dari hambatan non tarif, berapa banyak hambatan non tarif mengurangi perdagangan. Secara umum pendekatan quantity based measures yang menggunakan model gravity, mempunyai keunggulan empiris yang dicapai oleh model ini dalam ekonomi internasional, model ini bekerja dengan baik ketika perdagangan bilateral diregresikan pada GDP.

\section{METODE \\ Metode Analisis}

Penelitian ini menggunakan data panel dengan pendekatan gravity model. Variabel utama yang diperkirakan mempengaruhi ekspor kayu lapis Indonesia ke Negara tujuan ekspor utama adalah GDP, jarak ekonomi, nilai tukar Indonesia ke negara tujuan ekspor, dan indeks harga konsumen. Proksi ukuran ekonomi (economy size) yang digunakan dalam penelitian ini adalah GDP, GDP perkapita dan populasi. 
Penggunaan GDP juga digunakan oleh Alam, Uddin, dan Taufique (2009) namun untuk kasus impor di Bangladesh, Brodzicki dan Stanisław (2013). Sedangkan Dilanchiev (2012) menggunakan GDP perkapita untuk menganalisis pola perdagangan Negara Georgia. Menurut Dee (2010) GDP lebih menunjukkan market power, sedangkan GDP perkapita lebih menunjukkan consumption power. Pada beberapa penelitian seperti penelitian Khan, Haq, dan Khan (2013) menggunakan keduanya, baik GDP maupun GDP perkapita. Sedangkan penelitian Leitao (2010) menggunakan rata-rata GDP perkapita Negara pengekspor dan pengimpor. Selain ukuran ekonomi, jarak antar negara merupakan faktor yang penting dalam perdagangan karena dapat mempengaruhi biaya transportasi. Jarak dalam gravity model merupakan proksi untuk biaya transportasi (Thangavelu, 2010). Jarak yang digunakan dalam penelitian ini adalah jarak ekonomi yang diperoleh dari perhitungan perkalian GDP nominal negara tujuan dengan jarak geografis negara yang bersangkutan. Hasil dari perkalian tersebut dibagi kembali dengan GDP nominal negara eksportir. Penggunaan jarak ekonomi dilakukan pada model ini untuk menghindari adanya matriks singular yang diakibatkan oleh nilai yang konstan dari jarak geografis negara eksportir dan negara tujuan ekspor tiap tahunnya. Berkaitan dengan perdagangan bilateral antar negara, apabila jarak antar negara semakin dekat maka biaya transportasi dalam perdagangan dapat semakin berkurang sehingga ekspor akan semakin meningkat. Sedangkan sebaliknya, apabila jarak antar negara semakin jauh maka biaya transportasi yang dikeluarkan akan semakin besar sehingga akan menurunkan ekspor suatu negara (Thangavelu, 2010).

Gravity model pada penelitian ini mengacu pada penelitian Callaghan dan Uprasen (2008) dengan modifikasi penambahan variabel nilai tukar (ER) seperti pada model Dilanchiev (2012); Gull dan Hafiz (2011) dan dummy krisis. Secara detil spesifikasi model dalam penelitian ini adalah seperti persamaan satu.

$$
\begin{aligned}
& \log X_{i j t}=\alpha_{0}+\beta_{1} \log \text { GDP riil it }+ \\
& \beta_{2} \log \text { GDP riil jt }+\beta_{3} \log J E \text { ijt } \\
& +\beta_{4} \log C P I i t+\beta_{5} \log C P I j t+\beta_{6} \log E R \text { ijt } \\
& +\beta_{7} \log \text { Dkrisis }+\beta_{8} T j t+\varepsilon_{i j t} \ldots \ldots \ldots \ldots \ldots(1)
\end{aligned}
$$

\begin{tabular}{|c|c|}
\hline $\mathrm{X}_{\mathrm{ijt}}$ & $\begin{array}{l}=\text { Volume ekspor }(\%) \\
=\text { Konstanta }\end{array}$ \\
\hline ij & $=$ GDP riil negara Indonesia (\%) \\
\hline & $\begin{aligned}= & \text { GDP riil negara tujuan ekspor } \\
& \text { utama }(\%)\end{aligned}$ \\
\hline g JE & $\begin{aligned}= & \text { Jarak ekonomi Indonesia ke } \\
& \text { negara tujuan ekspor }(\%)\end{aligned}$ \\
\hline $\mathrm{g}$ CPI & $\begin{aligned}= & \text { Indeks harga konsumen negara } \\
& \text { Indonesia }(\%)\end{aligned}$ \\
\hline $\mathrm{C}$ & $\begin{aligned}= & \text { Indeks harga konsumen negara } \\
& \text { tujuan ekspor utama }(\%)\end{aligned}$ \\
\hline og EF & $\begin{aligned}= & \text { Nilai tukar riil Indonesia ke } \\
& \text { negara utama tujuan ekspor (\%) }\end{aligned}$ \\
\hline D & $\begin{aligned} & \text { dummy krisis keuangan } \\
& \text { tahun } 2010\end{aligned}$ \\
\hline & \\
\hline
\end{tabular}

Keterangan:

\section{Estimasi Rata-rata Tarif ekuivalen dari NTBs}

Penelitian ini menggunakan pendekatan a residual based method (Callaghan dan Uprasen, 2008). Pendekatan ini menghitung semua parameter yang diestimasi dari gravity model. Sesudah semua parameter diestimasi, aliran perdagangan potensial dapat diperoleh dengan mensubtitusikan seluruh data ke dalam gravity model yang diestimasi. The fitted trade flows 
dari gravity model dispesifikasikan sebagai aliran perdagangan potensial. Perbedaan antara aliran perdagangan aktual dan potensial mengindikasikan tarif ekuivalen NTBs (Park, 2002; Callaghan dan Uprasen, 2008; Walsh, 2008; Fontagne, Amelie, and Cristina, 2011; Anggoro, 2015). Residual $\varepsilon_{i j}$ pada persamaan (1) didefinisikan sebagai log impor aktual dari eksportir i ke importer j dikurangi log dari impor potensial dari prediksi gravity yang ditunjukkan pada persamaan berikut:

$$
\ln x_{i j}^{a}-\ln x_{i j}^{p}=(1-\sigma) \ln t_{i j}
$$

$x_{i j}^{a}=$ impor aktual negara $\mathrm{i}$ dari negara $\mathrm{j}$

$x_{i j}^{p}=$ impor potensial negara $\mathrm{i}$ dari negara $\mathrm{j}$

$t_{i j} \quad=$ unobservable trade cost

$\sigma=$ elastisitas konstan dari subtitusi antara semua komoditi

Tarif ekuivalen dari setiap negara diperoleh dari penjumlahan impor aktual dan potensial atas semua partner dagang. Kemudian untuk setiap negara j, $X_{j}^{a}=\sum x_{i j}^{a}$ dimana $\mathrm{i} \neq \mathrm{j}$ dan $X_{j}^{p}=\sum_{i} x_{i j}^{p}$ dimana $\mathrm{i} \neq \mathrm{j}$. Persamaan (2) ditransformasi menjadi persamaan (3) sehingga menjadi sebagai berikut:

$\ln X_{j}^{a}-\ln X_{j}^{p}=(1-\sigma) \ln t_{j}$

Disusun ulang, persamaan (3) menjadi:

$\ln \left(\begin{array}{c}x_{j}^{a} \\ x_{j}^{p}\end{array}\right)-\ln t_{j}=-\sigma \ln t_{j}$

Selanjutnya dengan mensubtitusi $\ln t_{j}$ dengan $\ln \left(\frac{x_{b}^{a}}{x_{b}^{p}}\right)$ dimana a,p, dan b adalah aktual, potensial dan benchmark. Sehingga persamaan (4) dapat ditulis kembali menjadi: $\ln \left(\frac{x_{j}^{a}}{x_{j}^{p}}\right)-\ln \left(\frac{x_{b}^{a}}{x_{b}^{p}}\right)=-\sigma \ln t_{j}$

Berdasarkan persamaan(5)dirumuskan tarif ekuivalen NTBs sebagai berikut:

$t_{j}=\exp \left\{\ln \left(\frac{x_{j}^{a}}{x_{j}^{p}}\right)-\ln \left(\frac{x_{b}^{a}}{x_{b}^{p}}\right)\right\} \frac{1}{\sigma}=\frac{\left(x_{j}^{a} / x_{j}^{p}\right)^{-\frac{1}{\sigma}}}{\left(x_{b}^{a} / x_{b}^{p}\right)}$

Keterangan:

$x_{j}^{a}=$ Volume ekspor aktual kayu lapis Indonesia ke negara tujuan

$x_{j}^{p}=$ Volume ekspor potensial kayu lapis Indonesia ke negara tujuan

$x_{b}^{a}=$ Volume ekspor aktual kayu lapis Indonesia ke negara benchmark

$x_{b}^{a}=$ Volume ekspor potensial kayu lapis Indonesia ke negara benchmark

$\sigma=$ Elastisitas substitusi kayu lapis Indonesia dengan kayu tropis lainnya yang diperoleh berdasarkan hasil penelitian dari Arunanondchai (2001) bernilai 1.9 .

Derivasi model gravity dapat dilihat juga di Tayyab, Ayesha, and Madiha (2012). Jarak ekonomi diperoleh berdasarkan rumus perhitungan dari Karlinda (2012) sebagai berikut:

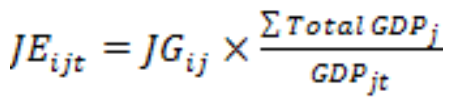

Keterangan:

$\mathrm{JE}_{\mathrm{ij}}=$ Jarak ekonomi negara $\mathrm{i}$ terhadap negara j pada tahun $t$

$J G_{i j}=$ Jarak geografis negara i terhadap negara $\mathrm{j}$

$\sum$ Total GDPj $=$ Total GDP negara $\mathbf{j}$ pada periode observasi

$\mathrm{GDP}_{\text {it }}=$ GDP negara $\mathrm{j}$ pada tahun $\mathrm{t}$

\section{Data}

Penelitian ini menggunakan data sekunder, yang meliputi data kuantitatif tahunan dan sekunder pada rentang waktu 2001-2011. Negara yang 
dimaksud dalam studi empiris ini yang merupakan Negara tujuan utama ekspor kayu lapis Indonesia adalah Jepang, RRT, Amerika Serikat, Korea Selatan,
Saudi Arabia, Uni Emirat Arab, Inggris, Belgia dan Singapura. Adapun jenis dan sumber data yang digunakan dalam penelitian ini dapat dilihat pada Tabel 1.

Tabel 1. Data, satuan, simbol dan sumber data

\begin{tabular}{|c|c|c|c|}
\hline Variabel & Satuan & Simbol & Sumber \\
\hline Volume ekspor & Ton & Xijt & UN Comtrade \\
\hline Nilai ekspor & USD & $x$ & UN Comtrade \\
\hline GDP riil Indonesia & USD & GDPriil it & Worldbank \\
\hline GDP riil negara tujuan & USD & GDPriil jt & Worldbank \\
\hline Jarak & $\mathrm{Km}$ & JE ijt & CEPII \\
\hline Indeks harga konsumen negara tujuan & & CPI jt & IMF \\
\hline \multicolumn{2}{|l|}{ Indeks harga konsumen Indonesia } & $\mathrm{CPI}$ it & IMF \\
\hline Nilai tukar Indonesia ke negara tujuan & $\begin{array}{l}\text { Yen, Yuan, USD, } \\
\text { Won, Riyal, Dirham, } \\
\text { Euro, Poundsterling, } \\
\text { SDR }\end{array}$ & Er ijt & UNCTAD \\
\hline Tarif & $\%$ & T jt & TRAINS \\
\hline
\end{tabular}

\section{HASIL DAN PEMBAHASAN}

\section{Faktor-Faktor yang Memengaruhi} Volume Ekspor Kayu Lapis Indonesia

Setelah mencoba beberapa estimasi model awal dengan memasukkan beberapa variabel sebagai proksi size ekonomi diantaranya PDB perkapita Indonesia dan mitra dagang, populasi serta proksi biaya transportasi yaitu jarak geografi, model terbaik diperoleh pada pengolahan data panel pada fixed effect model dengan melakukan pembobotan Seemingly Unrelated Regressions (SUR) pada cross section seperti yang disajikan pada Tabel 2. Model ini merupakan model terbaik karena telah melakukan respesifikasi model, Hasil estimasi model menunjukkan bahwa masing-masing variabel memiliki nilai probabilitas kurang dari a 5\%. Artinya, semua variabel yang digunakan tersebut signifikan atau berpengaruh nyata terhadap volume ekspor kayu lapis Indonesia dengan asumsi ceteris paribus. Probabilitas F-statistik pada model tersebut memiliki nilai 0,000000 kurang dari a $5 \%$ yang berarti variabelvariabel yang digunakan pada model berpengaruh nyata terhadap volume ekspor kayu lapis Indonesia dengan asumsi ceteris paribus. 
Tabel 2. Hasil Estimasi Variabel yang Berpengaruh terhadap Volume Ekspor Kayu Lapis Indonesia

\begin{tabular}{lcrr}
\hline Variabel & Koefisien & t-statistic & Probabilitas \\
\hline GDPiriil(logGDPi riil) & 1.318051 & 4.046212 & 0.0001 \\
GDPjriil(logGDPj riil) & 0.946884 & 6.375664 & 0.0000 \\
JE (logDistijekonom) & -0.147901 & -2.364540 & 0.0204 \\
CPli (logCPli) & -4.045122 & -22.49964 & 0.0000 \\
CPlj (logCPIj) & 2.350624 & 9.490506 & 0.0000 \\
Dkrisis & 0.175906 & 5.819359 & 0.0000 \\
Erij (logErij) & 1.260692 & 9.534674 & 0.0000 \\
Tarif & -0.000265 & -0.022472 & 0.9821 \\
C & -19.820017 & -2.982103 & 0.0038 \\
\hline \multicolumn{4}{c}{ Weighted Statistics } \\
\hline R-squared & 0.979614 & Sum square resid \\
Prob (F-statistic) & 0.000000 & Durbin-Watson stat & 94.54567 \\
\hline \multicolumn{4}{c}{ Unweighted Statistics } \\
\hline R-squared & \multicolumn{2}{c}{ Durbin-Watson stat } \\
Sum square resid & 9.061787 & 1.142323 \\
\hline
\end{tabular}

Sumber: Hasil estimasi, diolah

Nilai $R$-squared sebesar 0.979614 menunjukkan secara keseluruhan model dapat dijelaskan oleh variabelvariabel yang di dalam model sebesar $97.9614 \%$, sedangkan $2.0386 \%$ sisanya dijelaskan oleh variabel lain diluar model. Model estimasi menggunakan model fixed effect dengan pembobotan GLS cross section SUR sehingga masalah heteroskedastisitas dapat diatasi. Nilai korelasi antar variabel independen kurang dari 0.80 , artinya tidak ada interaksi antar variabel independen pada model sehingga tidak terdapat masalah multikolinearitas. Hasil estimasi uji asumsi normalitas menunjukkan nilai probabilitas Jarque Bera $=0.577603$ lebih besar dari $\alpha 5 \%$. Artinya, model estimasi memiliki residual yang menyebar normal. Nilai Durbin Watson model estimasi $=2.033754$ berada pada rentang du (1.8501) dan 4-du (2.1499), artinya tidak terdapat masalah autokorelasi pada model estimasi volume ekspor kayu lapis Indonesia.
Hasil estimasi pada Tabel 2, diketahui bahwa setiap kenaikan GDP riil Indonesia sebesar $1 \%$ maka volume ekspor kayu lapis Indonesia ke negara tujuan ekspor utama akan meningkat sebesar $1.3 \%$ dengan asumsi ceteris paribus. Pada pendekatan gravity model, GDP riil menunjukkan ukuran perekonomian dari suatu negara. Negara Indonesia dengan GDP riil yang besar menunjukkan kapasitas produksi yang besar dari negara tersebut (Hatab, Romstad, dan Huo (2010). Semakin besar GDP riil negara eksportir maka semakin besar pula produktivitas yang dihasilkan sehingga ekspor akan cenderung meningkat.

Sementara untuk GDP riil negara tujuan ekspor utama kayu lapis Indonesia menunjukkan potensi pasar suatu negara. Tingkat pendapatan negara tujuan ekspor ini memiliki korelasi positif terhadap perdagangan antar negara (Thangavelu 2010). Pada hasil estimasi 
diketahui bahwa setiap kenaikan GDP riil negara tujuan ekspor utama kayu lapis Indonesia sebesar 1\%, maka akan meningkatkan volume ekspor kayu lapis Indonesia sebesar $0.95 \%$ dengan asumsi ceteris paribus.

Variabel jarak ekonomi antara Indonesia dengan negara tujuan ekspor signifikan berpengaruh negatif terhadap volume ekspor kayu lapis Indonesia. Peningkatan jarak ekonomi sebesar $1 \%$ akan menurunkan volume ekspor kayu lapis Indonesia ke negara tujuan ekspor utama kayu lapis Indonesia sebesar $0.15 \%$ dengan asumsi ceteris paribus. Jarak ekonomi merupakan proksi dari biaya transportasi. Semakin jauh jarak negara tujuan ekspor utama kayu lapis Indonesia dapat menurunkan volume ekspor kayu lapis Indonesia karena biaya transportasi yang ditanggung menjadi lebih besar.

Hasil estimasi model menunjukkan bahwa variabel indeks harga konsumen Indonesia memiliki pengaruh negatif dan signifikan terhadap volume ekspor kayu lapis Indonesia. Setiap terjadi peningkatan indeks harga konsumen di Indonesia sebesar $1 \%$, maka volume ekspor kayu lapis Indonesia menurun sebesar $4.05 \%$ dengan asumsi ceteris paribus.

Sedangkan indeks harga konsumen negara tujuan memiliki pengaruh signifikan positif terhadap volume ekspor kayu lapis Indonesia. Setiap terjadi peningkatan indeks harga konsumen sebesar $1 \%$ maka volume ekspor kayu lapis Indonesia akan meningkat sebesar $2.35 \%$ dengan asumsi ceteris paribus. Indeks harga konsumen di negara asing meningkat menunjukkan harga barangbarang Negara asing relatif lebih mahal dibandingkan barang-barang produksi Indonesia. Hal ini juga menunjukkan kayu lapis Indonesia relatif lebih murah (meningkat daya saingnya) sehingga meningkatkan ekspor kayu lapis Indonesia ke negara tujuan ekspor

Variabel nilai tukar mata uang rupiah terhadap masing-masing negara tujuan ekspor utama kayu lapis Indonesia memiliki pengaruh signifikan secara positif terhadap volume ekspor kayu lapis Indonesia. Nilai tukar rupiah yang digunakan merupakan nilai tukar rupiah per masing-masing negara tujuan ekspor kayu lapis. Misalkan, Negara tujuan ekspor kayu lapis Indonesia adalah Jepang (nilai tukar rupiah terhadap yen Jepang) berarti ketika terjadi kenaikan besaran nilai mata uang rupiah terhadap besaran yen atau rupiah terdepresiasi terhadap yen sebesar $1 \%$ menyebabkan volume ekspor kayu lapis Indonesia ke Jepang meningkat sebesar $1.26 \%$ dengan asumsi ceteris paribus.

Variabel krisis keuangan Uni Eropa tahun 2010 berpengaruh terhadap volume ekspor kayu lapis Indonesia ke negara tujuan ekspor utama. Ekspor kayu lapis Indonesia rata-rata lebih tinggi 0.17 pada saat sebelum krisis dibandingkan pada saat krisis Uni Eropa pada tahun 2010. Krisis Uni Eropa tahun 2010 berdampak pada penurunan permintaan Negara tujuan ekspor utama terhadap kayu lapis Indonesia. Selanjutnya ini menyebabkan volume ekspor kayu lapis Indonesia rata-rata lebih tinggi sebelum krisis dibandingkan saat krisis Uni Eropa tahun 2010.

\section{Perhitungan Rata-rata Tarif ekuivalen Ekuivalen dari NTBs di Masing- Masing Negara Tujuan Ekspor Utama Kayu Lapis Indonesia \\ Perhitungan rata-rata tarif ekuivalen} dari NTBs memperlihatkan bahwa di beberapa negara tertentu yang sudah memberlakukan penurunan tarif terhadap kayu lapis Indonesia, cenderung menerapkan NTBs. Hasil 
perhitungan pada Tabel 3 menunjukkan bahwa Negara Jepang sebagai Negara benchmark memiliki rata-rata tarif ekuivalen NTBs komoditi kayu lapis sebesar $100 \%$. Sedangkan rata-rata tarif ekuivalen NTBs Negara tujuan ekspor kayu lapis Indonesia yang lain lebih besar dari 100\%. Besarnya tarif ekuivalen tersebut menunjukkan bahwa masih banyak persyaratan serta regulasi yang harus dipenuhi terkait dengan ekspor kayu lapis Indonesia. Meskipun kayu lapis Indonesia memiliki daya saing di negara-negara tujuan ekspor utama, namun pada kenyataannya NTBs tetap ada dan menjadi tantangan bagi negara eksportir seperti Indonesia.

Rata-rata tarif ekuivalen dari NTBs terbesar untuk kayu lapis Indonesia diberlakukan oleh Inggris dengan ratarata tarif ekuivalen sebesar $532.56 \%$. Belgia, juga memiliki rata-rata tarif ekuivalen yang besar yaitu sebesar $344.16 \%$. Hal ini menunjukkan bahwa walaupun nilai tarif kayu lapis memiliki kecederungan yang semakin menurun dengan berbagaikomitmen perdagangan yang telah disepakati, namun rata-rata tarif ekuivalen NTBs yang diberlakukan Negara-negara tujuan ekspor relatif masih tinggi. Terkait rata-rata tarif ekuivalen NTBs yang tinggi tersebut Indonesia dan Uni Eropa mengadakan perjanjian sukarela FLEGT-VPA terkait dengan hutan beserta produk yang dihasilkan termasuk kayu lapis. Pada implementasinya, FLEGT-VPA merupakan instrumen kebijakan yang melengkapi kesepakatan Reducing Emisions From Deforestation and Forest Degradation REDD (Kementerian Kehutanan, 2011). Adanya FLEGTVPA dapat meningkatkan mekanisme penerapan REDD. Terkait dengan isu mengenai standar dan mutu produk ekspor, pemerintah Indonesia melalui Mutu Certification International melakukan kerjasama dengan lembaga Forest Standard Center(FSC)padatahun 2004 untuk mengatasi permasalahan sertifikasi bidang kehutanan. Adanya kerjasama tersebut dapat menurunkan biaya sertifikasi sehingga menjadi lebih ekonomis.

Selain Uni Eropa, Amerika Serikat memiliki rata-rata tarif ekuivalen NTBs yang cukup besar bagi Indonesia. Hambatan non tarif tersebut salah satunya berupa peraturan mengenai standarisasi yang tertuang dalam American Legal Lacey. Kebijakan Legal Lacey Act yang dikeluarkan oleh Amerika Serikat memiliki tujuan utama untuk mencegah adanya peredaran produk kayu ilegal (Kementerian Kehutanan, 2011).

Jepang memiliki rata-rata tarif ekuivalen NTBs relatif lebih rendah dibanding Negara tujuan ekspor lainnya. Sejak tahun 2006 Jepang memberlakukan sistem Green Purchasing Law yang mewajibkan instansi-instansi pemerintahannya membeli produk kayu legal (Kementerian Kehutanan, 2011). Selain itu sejak tahun 1990 Jepang menerapkan program Green Konyuho yaitu sertifikasi pelabelan ramah lingkungan. Sertifikasi tersebut dipercayakan Jepang kepada Indonesia melalui PT Mutu Agung Lestari (MAL) yang sebelumnya dilakukan oleh petugas dari Japanese Agriculture Standard (JAS). PT MAL dapat melakukan sertifikasi untuk produk-produk kayu dari negara-negara ASEAN, Papua Nugini, dan Timor Timur. Dengan adanya perusahaan sertifikasi itu, produkproduk kayu dari Indonesia sebenarnya lebih mudah diekspor karena sertifikasi produk dapat dilakukan di dalam negeri. Eksportir dapat lebih mudah memproses sertifikasi, sehingga bisa menghemat 
waktu dan biaya (Widyastutik dan Arianti, 2014)

Rata-rata tarif ekuivalen NTBs RRT sebesar $251.19 \%$. RRT berkomitmen agar industri perkayuan yang berkembang di RRT harus menggunakan bahan baku yang legal. Sedangkan rata-rata tarif ekuivalen NTBs Korea Selatan sebesar 191.7, terkait dengan peraturan mengenai illegal logging dari asal bahan baku kayu lapis. Indonesia dan Singapura telah menyepakati pemberlakuan tarif $0 \%$ bersama dengan negara anggota ASEAN lainnya. Adanya ketetapan tersebut mengakibatkan masing-masing negara memprioritaskan terhadap hambatan non-tarif. Singapura memiliki nilai NTBs sebesar $413.59 \%$.

Tabel 3. Rata-rata Tarif ekuivalen NTBs Kayu Lapis Indonesia di Negara Tujuan Ekspor Utama

\begin{tabular}{lr}
\hline Negara & NTBs (\%) \\
\hline Jepang & 100 \\
RRT & 251.19 \\
Amerika & 406.17 \\
Korea Selatan & 191.75 \\
Saudi Arabia & 191.75 \\
Uni Emirat Arab & 187.16 \\
Belgia & 230.97 \\
Inggris & 344.16 \\
Singapura & 532.56 \\
\hline
\end{tabular}

Rata-rata rata-rata tarif ekuivalen dari NTBs Saudi Arabia sebesar $187.16 \%$ dan Uni Emirat Arab sebesar $230.97 \%$, terkait hal tersebut pada tahun 2009, Komite Akreditasi Nasional (KAN) melakukan penandatangan naskah kerjasama bilateral dengan Arab Saudi (Saudi Arabian Standard Organization/ SASO) untuk mempererat hubungan teknis dan ekonomi melalui penghilangan atau pengurangan hambatan teknis perdagangan antarnegara (KAN 2013). Produk yang diekspor Indonesia tidak perlu lagi menjalani pengecekan laboratorium di negara tersebut, namun cukup dilakukan di Indonesia. Dampaknya terjadi peningkatan ekspor kayu lapis Indonesia dari USD 284804 juta ditahun 2010, meningkat menjadi USD 311341 juta ditahun 2011 (Puska Daglu, 2012).

Adanya SVLK yang sudah berlaku di Indonesia menjadi jalan keluar bagi tuntutan serta kebutuhan Indonesia sebagai negara produsen. SVLK yang diberlakukan di Indonesia mulai diakui oleh negara mitra dagang sebagai penunjuk legalitas kayu Indonesia. Negara-negara yang telah mengakui SVLK Indonesia adalah Amerika Serikat, Uni Eropa termasuk didalamnya Belgia dan Inggris dan Jepang. Sementara untuk negara-negara lainnya masih dalam proses perundingan (Kementerian Kehutanan, 2011).

\section{KESIMPULAN DAN REKOMENDASI KEBIJAKAN}

Hasil estimasi menunjukkan GDP riil negara eksportir dan importir, jarak ekonomi antar negara eksportir dan importir, indeks harga konsumen negara eksportir dan importir, nilai tukar negara eksportir terhadap masing-masing negara importir berpengaruh signifikan terhadap volume ekspor kayu lapis Indonesia. Selain itu krisis keuangan Uni Eropa 2010 juga berpengaruh terhadap volume ekspor kayu lapis Indonesia.

Hasil perhitungan rata-rata tarif ekuivalen NTBs menunjukkan negaranegara Uni Eropa seperti Inggris dan Belgia memiliki rata-rata tarif ekuivalen NTBs terbesar daripada negaranegara tujuan ekspor utama kayu lapis lainnya. Berdasarkan hasil analisis, rata-rata tarif ekuivalen NTBs yang 
diberlakukan oleh negara tujuan ekspor utama Indonesia masih tergolong tinggi. Dari temuan studi ini, kebijakan yang direkomendasikan pertama, berdasarkan hasil model gravity, koefisien CPI dan nilai tukar tertinggi dibandingkan dengan koefisien variabel lain. Implikasi kebijakannya adalah untuk meningkatkan kinerja ekspor kayu lapis pemerintah seyogyanya menjaga kestabilan inflasi (yang diproksi dengan CPI) dan nilai tukar rupiah. Kedua, terkait dengan rata-rata tarif ekuivalen NTBs yang masih tinggi dari Negara tujuan ekspor, pemerintah diharapkan melakukan fasilitasi perdagangan berupa harmonisasi regulasi terkait standar produk kehutanan mitra dagang Indonesia bagi produsen kayu maupun eksportir kayu.

\section{UCAPAN TERIMA KASIH}

Pada kesempatan ini penulis memberikan ucapan terima kasih untuk pihak-pihak yang membantu tersusunnya tulisan ini. Ucapan terima kasih disampaikan kepada Keluarga Besar Departemen Ilmu Ekonomi, Fakultas Ekonomi dan Manajemen yang telah memberikan iklim berkarya sehingga penulis dapat menyelesaikan tulisan ini. Ucapan terima kasih juga disampaikan kepada Pusat Kebijakan Perdagangan Internasional, Kementerian Perdagangan yang secara tidak langsung memberikan ide untuk menulis topik mengenai hambatan non tarif yang dikenakan pada produk ekspor komoditas kayu lapis.

\section{DAFTAR PUSTAKA}

Alam, Md. M; Md.,G. S. Uddin; , K. Md. R. Taufique. (2009). Import Inflows of Bangladesh: The Gravity Model Approach. International Journal of Economics and Finance. Vol. 1. No. 1., February 2009.
Anggoro, R. (2015). Hambatan Non Tarif dan Faktor-faktor yang Memengaruhi Ekspor Kakao Indonesia ke Pasar Eropa. Skripsi. Bogor: Institute Pertanian Bogor.

Arunanondchai, M. (2001). Trade Policy and the Welfare of Southeast-Asian Timber Exporters: Some Implications for Forest Resourses. Department Of Economics University of Warwick (UK).

Brodzicki, T. dan U. Stanisław. (2013). International trade relations of enterprises established in Poland's regions: gravity model panel estimations. Institute for Development. Working Paper No.001 / 2013.

Callaghan, B., A. and Uprasen, U (2008). Impact of the $5^{\text {th }} E U$ Enlargement on ASEAN. Euro-Asia Centre (EAC), Departement of Economics Kemmy Business School University of Limerick, Ireland.

Dee, P. (2010). Services Liberalisation toward the ASEAN Economic Community. Paper prepared for report on Tracing the Progress toward the ASEAN Economic Community. Jakarta: Economic Research Institute for ASEAN and East Asia (ERIA).

Dilanchiev, A. (2012). Empirical Analysis of Georgian Trade Partner: Gravity Model. Journal of Social Sciences, 1(1):7578,2012 ISSN:2233-3878.

Dinas Kehutanan Provinsi Jawa Barat. (2015). Penyelundupan Tekan Industri Kayu Domestik. Diunduh Tanggal 18 Januari 2015 dari http://www.dishut. jabarprov.go.id/?mod=detilBerita\&idMe nuKiri $=334 \&$ idBerita $=336$.

Dwiprabowo, H. (2009). Analisis Daya Saing Ekspor Panel-Panel Kayu Indonesia dan Malaysia. Puslitsosek Dephut. Vol. 6(2), pp.151-160.

Fontagne, L., G. Amelie, and M. Cristina. (2011). Estimations of Tariff of Equivalents for the Services Sector. CEPII No. 2011-24 December. 
Gul, N. dan M.Y. Hafiz. (2011). The Trade Potential of Pakistan: An Application of the Gravity Model. The Lahore Journal of Economics 16 : 1 (Summer 2011): pp. 23-62.

Hatab, A., E. Romstad, X. Huo. (2010). Determinants of Egyptian Agricultural Exports: A Gravity Model Approach. Modern Economy. 134-143 doi:10.4236/ me.2010.13015 Published Online November 2010. Tersedia di http://www. SciRP.org/journal/me.

Jager, H. and G. Lanjouw. (1977). An Alternative Method for Quantifying International Trade Barriers. Review of World Economics. Vol.113, issues 4, pages 719-740.

Kementerian Kehutanan

(2011).

Kesepakatan Kemitraan Sukarela FLEGT antara Indonesia dan Uni Eropa. Pusat Kerjasama Luar Negeri. Diunduh tanggal 12 Desember 2013. Tersedia di http://www.euflegt.efi.int/documents.

Kementerian Keuangan. (2013). ASEAN Free Trade Area. Diunduh tanggal 12 Desember 2013 dari http://www.tarif. depkeu.go.id/others/?hi=AFTA.

Kementerian Negara Lingkungan Hidup. (2006). Status Lingkungan Hidup Indonesia tahun 2006. Jakarta: Kementerian Negara Lingkungan Hidup.

Kementerian Perdagangan. (2013). Produk Hasil Hutan. Diunduh 12 Januari 2014. Tersedia di http://inatrims.kemendag. go.id/id/product/detail/fores-products9.

Khan, S., I. Haq. and K. Dilawar. (2013). An Empirical Analysis of Pakistan's Bilateral Trade: A Gravity Model Approach. The Romanian Economic Journal. Year XVI No. 48. June 2013.

Komite Akreditasi Nasional. (2013). Kerjasama SASO-Saudi Arabia. Diunduh tanggal 26 Maret 2012 dari http://www.kan.or.id/?page_ id $=568 \&$ lag $=i d$.

Leitao, N. C. (2010). The Gravity Model and United State's Trade. European
Journal of Economic, Finance and Administrative Science. Issue 20: pp. 92-100 http://www.eurojournals.com.

Park, S. C. (2002). Measuring Tariff Equivalents in Cross Border Trade in Service. KIEP (Korea Institute for International Economic Policy) working Paper 02-15.

Pusat Kebijakan Perdagangan Luar Negeri (Puska Daglu). (2012). Kajian Kebijakan Mutu dan Standar Produk Ekspor Tertentu dalam Meningkatkan Daya Saing. Laporan Penelitian. Jakarta: Kementerian Perdagangan.

Salvatore. (2007). International Economics. $9^{\text {th }}$ Edition. John Wiley dan Sons Inc.

Tayyab, M., T. Ayesha, and M. Madiha. (2012). Review of Gravity Model Derivation. Mathematical Theory and Modelling Vol. 2. No. 9, 2012.

Thangavelu, S. M. (2010). Non-Tariff Barriers, Integration and Export Growth in ASEAN. Department of Economics National University of Singapore.

Triastuti, S. (1992). Peranan Kebijaksanaan Perdagangan Luar Negeri Terhadap Perkembangan Ekspor Kayu Lapis Indonesia di Pasar Dunia. Bogor: Institut Pertanian Bogor).

UN Comtrade Database. (2013). Diunduh tanggal 10 Januari 2014 dari http:// unstats.un.org/unsd/tradekb/ Knowledgebase/4.

Walsh, K. (2008). Trade in Services: Does Gravity Hold? Journal of World Trade. Vol.42(2). pp. 315-334.

Widyastutik dan R. K. Arianti. (2014). Analisis Strategi Kebijakan Mutu dan Standar Produk Kayu Lapis dalam Rangka Meningkatkan Daya Saing Ekspor. Journal of Indonesia Agribusiness. Volume 2. No 1-June 2014.

World Trade Organization. (2013a). Technical Information on Technical Barriers to Trade. Diunduh tanggal 13 Januari 2014 dari :http://www.wto.org/ english/tratop_e/tbt_e/tbt_info_e.htm. 
World Trade Organization. (2013b). Technical Information on Safeguard Measures. Dinduh tanggal 13 Januari 2014 dari: http://www.wto.org/english/ tratop_e/safeg_e/safeg_info_e.htm.

World Trade Organization. (2013c). Sanitary and Phytosanitary Measures. Diunduh tanggal 13 Januari 2014 dari: http:// www.wto.org/english/tratop_e/sps_e/ sps e.htm.

World Wild Foundation. (2009). Deforestasi. Diunduh tanggal 15 Januari 2014 dari: http://www.wwf.or.id/?10741/ Deforestasi. 